\title{
Characteristics of $\alpha$-Amylase Induced in Distal Half-grains of Wheat
}

\author{
Ablet Hader, Kazuhide Rikiishi, Ahmed Nisar and Kazuhiko Noda* \\ Research Institute for Bioresources, Okayama University, 2-20-1 Chuo, Kurashiki, Okayama 710-0046, Japan
}

$\alpha$-Amylase activity was measured in distal half-grains of four wheat lines, RL4137, OS21-5, Shirogane-komugi (Shirogane) and Hokkai250, after $72 \mathrm{~h}$ soaking at $20^{\circ} \mathrm{C}$. The half-grains of RL4137 and Hokkai250 at the maturity stage (about $15 \%$ water content) showed a significantly $(\mathrm{P}<0.01)$ higher $\alpha$-amylase activity after $72 \mathrm{~h}$ soaking $(3.95 \mathrm{mU} / \mathrm{mg}$, and $2.14 \mathrm{mU} / \mathrm{mg}$, respectively) than those of OS21-5 and Shirogane $(1.05 \mathrm{mU} / \mathrm{mg}$ and $0.91 \mathrm{mU} / \mathrm{mg}$ ). During grain development, 30 to 50 days postanthesis (DPA), soaking also induced the production of $\alpha$-amylase in the half-grains of RL4137 after 72 h. The $\alpha$-amylases induced consisted of heat-labile $\alpha$ AMY2 (low pI) type of enzymes. They were similar to $\alpha$-AMY2 which was reported to be induced in the developing pericarp in the absence of stimulus from gibberellic acid (GA), but different from heat-resistant $\alpha$ AMY2 expressed in the aleurone tissue after stimulation by GA. It is suggested that the RL4137 aleurone tissue has a potential for the synthesis of heat-labile $\alpha$-AMY2, although the level of induced $\alpha$-amylase activity was very low compared with that of the enzyme synthesized in the embryo and endosperm at the time of germination.

Key Words: $\alpha$-amylase, aleurone, heat-labile, wheat.

\section{Introduction}

Pre-harvest sprouting of wheat induces the production of $\alpha$-amylase in grain and causes the deterioration of the end-use quality of flour. It is well known that $\alpha$-amylase synthesis in grain is enhanced in the embryo and aleurone tissue by gibberellic acid (GA) and suppressed by abscisic acid (ABA). Wheat grains express three distinct $\alpha$-amylase isozyme families during development and at the time of germination: $\alpha$-AMY1 (Sargeant 1980), $\alpha$-AMY2 (Sargeant 1980 ) and $\alpha$-AMY3 (Daussant and Renard 1987). The $\alpha$ AMY1 isozyme (malt/germination amylase) is mainly expressed in germinating grains, while $\alpha$-AMY2 (green/pericarp amylase) is induced in the developing pericarp and at the later stages of germination, around 5 or 6 days after wetting (Marchylo et al. 1979, Marchylo et al. 1980, Nishikawa and Watanabe 1988). The $\alpha$-AMY3 isozyme has been de-

Communicated by Y. Furuta

Received October 21, 2002. Accepted November 27, 2002.

*Corresponding author (e-mail: knoda@rib.okayama-u.ac.jp) tected only in the developing pericarp (Daussant and Renard 1987). However, Gale et al. (1983a) and Kettlewell et al. (1999) noticed that some wheat lines contained higher than usual levels of $\alpha$-amylase in non-germinated grain. Gale et al. (1983a) suggested that the $\alpha$-amylases in non-germinated grain belonged to the $\alpha$-AMY1 family and were synthesized due to the enhanced sensitivity of the aleurone tissue to a stimulus like GA. It remains to be determined, however, where and how the stimulus is generated.

In barley, the production of low $\mathrm{pI}$ isozymes of $\alpha$ amylase was induced in distal half-grains after $78 \mathrm{~h}$ soaking and the activity level reached about $35 \%$ of the activity in the $\mathrm{GA}_{3}$-treated half-grains after $112 \mathrm{~h}$ (MacGregor 1976). Cornford et al. (1986) also observed increased levels of $\alpha$ amylase activity in distal half-grains collected 25-28 days after anthesis when they were incubated in a simple buffer solution for $72 \mathrm{~h}$. In a study of the wheat variety Spica, Mares and Gale (1990) observed that the production of $\alpha$-amylase was induced uniformly in the entire aleurone tissue rather than gradually from the region adjacent to the embryo to the distal region of grain. This progression normally occurs in $\alpha$-amylase production by GA stimulus from the embryo.

In this paper, we studied the $\alpha$-amylase production in the distal half-grains of four wheat lines. Two out of the four lines showed a significantly higher $\alpha$-amylase production than the others. The $\alpha$-amylases synthesized consisted of heat-labile $\alpha$-AMY 2 and might be encoded by $\alpha$-Amy 2 genes different from the $\alpha$-Amy 2 genes expressed in the aleurone tissue after stimulation by GA.

\section{Materials and Methods}

Treatments of embryos and distal half-grains

Wheat (Triticum aestivum L.) lines, RL4137 (redgrained, preharvest sprouting-resistant), OS21-5 (redgrained, preharvest sprouting-resistant), Shirogane-Komugi (Shirogane, red-grained, moderately susceptible to preharvest sprouting) and Hokkai250 (red-grained, preharvest sprouting-resistant) were selected out of 68 wheat lines which were subjected to a preliminary examination of the $\alpha$-amylase induction in distal half-grains. Spikes of RL4137, OS21-5, Shirogane and Hokkai250 were tagged at anthesis and harvested at five-day intervals from 30 to 55 DPA. At around $55 \mathrm{DPA}$, the grains reached harvest maturity (water content, about $15 \%$ ). Grains were sterilized by treatment with $70 \% \mathrm{EtOH}$ for $1 \mathrm{~min}, 5 \% \mathrm{NaClO}$ for $30 \mathrm{~min}$ and then rinsed five times with distilled water. Embryos were dissected out with a surgical knife on a clean bench (AIRTECH, Japan) after $1 \mathrm{~h}$ soaking. Distal half-grains (half-grain) were 
obtained by cutting off half part of the grains with embryos. Ten half-grains and twenty embryos were incubated in a Petri dish ( $9 \mathrm{~cm}$ in dia.) with 2 filter papers (No2. ToyoRoshi, Japan) moistened with $6 \mathrm{ml}$ of distilled water. These samples were kept at $-80^{\circ} \mathrm{C}$ for two month before the assay. To characterize the $\alpha$-amylase synthesized in the embryos and half-grains, the half grains of RL4137 were incubated in the following solutions: distilled water, $1 \mu \mathrm{M} \mathrm{GA}_{3}, 10,20,30$ and $40 \mu \mathrm{M}$ ABA, $20 \mathrm{mM}$ and $80 \mathrm{mM}$ glucose. Twenty embryos of RL4137 were also treated with the same solutions except for $1 \mu \mathrm{M} \mathrm{GA}_{3}$. Each Petri dish was kept at $20^{\circ} \mathrm{C}$ for $72 \mathrm{~h}$. Embryos and half-grains were weighed before the incubation. All the experiments were performed in triplicate and analyzed statistically by Duncan's multiple range test.

\section{Alpha-amylase assay}

Twenty embryos and ten half-grains were homogenized with $1 \mathrm{ml}$ of extraction buffer $(50 \mathrm{mM}$ Tris- $\mathrm{HCl}, 10$ $\mathrm{mM} \mathrm{CaCl}, \mathrm{pH} 7.5)$ in a glass homogenizer on ice. The homogenized solution was centrifuged at $12,000 \mathrm{rpm}, 4^{\circ} \mathrm{C}$ for $10 \mathrm{~min}$. The $\alpha$-amylase activity of the supernatant fluid was measured using the NeoAmylase Test (blue starch tablet, Daiichi Pure Chemicals, Japan) according to the manufacturer's instructions, which were based on the method of Barnes and Blakeney (1974). The reaction mixture contained $100 \mu \mathrm{l}$ of the supernatant fluid or an appropriate dilution, made up to $4.0 \mathrm{ml}$ with assay buffer $(20 \mathrm{mM}$ $\mathrm{NaHC}_{4} \mathrm{H}_{2} \mathrm{O}_{2} \cdot 3 \mathrm{H}_{2} \mathrm{O}, 10 \mathrm{mM} \mathrm{CaCl}, \mathrm{pH} 6.2$ ). This mixture was pre-incubated at $37^{\circ} \mathrm{C}$ for $5 \mathrm{~min}$, after which one NeoAmylase Test tablet was added and the resulting mixture was vortexed. After further incubation at $37^{\circ} \mathrm{C}$ for $30 \mathrm{~min}$, the reaction was stopped with $1 \mathrm{ml}$ of $0.5 \mathrm{~N} \mathrm{NaOH}$ and the mixture was centrifuged at $2,000 \mathrm{rpm}$ for $5 \mathrm{~min}$. The absorbance of the supernatant fluid was read at $620 \mathrm{~nm}$ and the reading was converted to enzyme activity units using a standard curve constructed with barley $\alpha$-amylase activity (Type VIII-A, Sigma).

\section{Heat stability}

The crude extract solution of RL4137 was maintained at $50,55,60,65$ and $70^{\circ} \mathrm{C}$ for $15 \mathrm{~min}$. The $\alpha$-amylase activity was assayed using the NeoAmylase Test as described above.

\section{Isozymes of $\alpha$-amylase}

Crude extracts of $\alpha$-amylase were prepared from the embryos and half-grains incubated in water and $1 \mu \mathrm{M} \mathrm{GA}_{3}$, as described above. Half of the extract solution was treated at $70^{\circ} \mathrm{C}$ for $15 \mathrm{~min}$. The $\alpha$-amylase isozymes were separated by the isoelectric focusing method of Sargeant and Walker (1978). Filter paper wicks $(5 \times 5 \mathrm{~mm})$ onto which $100 \mu \mathrm{l}$ of the extract solution had been adsorbed were applied to the cathode side of polyacrylamide gels $(210 \times 105 \mathrm{~mm})$ containing carrier Pharmalite (Pharmacia, Sweden) in the $\mathrm{pH}$ range of 4.5 to 8.0. A constant power of $1000 \mathrm{~V} / 10 \mathrm{~W}$ was circulated through the gels at $4^{\circ} \mathrm{C}$, with the paper wicks for $30 \mathrm{~min}$ and then without the wicks for $250 \mathrm{~min}$. The gel was immersed in 3\% $\beta$-limit dextrin (Megazyme, Ireland) at $4{ }^{\circ} \mathrm{C}$ for $10 \mathrm{~min}$, taken out from the dextrin solution, and kept at $37^{\circ} \mathrm{C}$ for $30 \mathrm{~min}$. Zymograms were obtained by immersion of the gel in the $\mathrm{I}_{2}-\mathrm{KI}$ solution $(8 \mathrm{~g} / \mathrm{L}$ and $1.27 \mathrm{~g} / \mathrm{L}$, respectively) for $30 \mathrm{~min}$ and rinsed with water for $5 \mathrm{~min}$.

\section{Results}

\section{$\alpha$-Amylase activity in the distal half-grains}

The half-grains of the four wheat lines, harvested at 55 DPA, showed a very weak $\alpha$-amylase activity in the range of $0.53 \mathrm{mU} / \mathrm{mg}$ (OS21-5) to $1.39 \mathrm{mU} / \mathrm{mg}$ (Shirogane) before soaking (Fig. 1A). After $72 \mathrm{~h}$, the $\alpha$-amylase activity increased significantly $(\mathrm{P}<0.01)$ in Hokkai250 $(1.89 \mathrm{mU} / \mathrm{mg}$ at $48 \mathrm{~h}$ and $2.14 \mathrm{mU} / \mathrm{mg}$ at $72 \mathrm{~h}$ from the initial value of 1.0 $\mathrm{mU} / \mathrm{mg}$ ) and in RL4137 (3.95 mU/mg at $72 \mathrm{~h}$, up from 0.72 $\mathrm{mU} / \mathrm{mg}$ at the initial stage). On the other hand, OS21-5 and Shirogane did not show an increase in the $\alpha$-amylase activity after $72 \mathrm{~h}$. The $\alpha$-amylase induction was also evaluated in the half-grains of RL4137 and Shirogane during grain development (Fig. 1B). More $\alpha$-amylase was induced in the halfgrains of RL4137 than in those of Shirogane from 30 to 55 DPA, especially at 50 and 55 DPA. On the other hand, Shirogane did not show any significant increase during grain
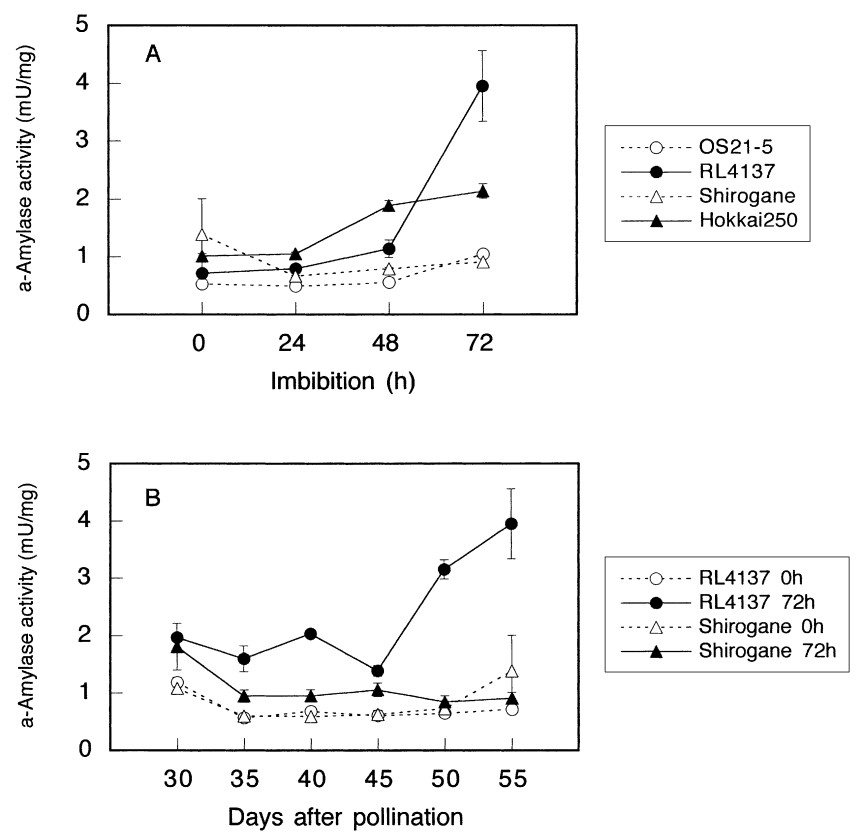

Fig. 1. $\alpha$-Amylase induction in the distal half-grains of wheat lines. (A) $\alpha$-Amylase activity in the distal half-grains of the wheat lines OS21-5, RL4137, Shirogane and Hokkai250 incubated with distilled water for 72 hours. Grains were collected at 55 days postanthesis (DPA).

(B) $\alpha$-Amylase activity in the distal half-grains of the wheat lines RL4137 and Shirogane which were collected from 30 to 60 DPA at intervals of 5 days. The grains were incubated with distilled water for 72 hours.

Bars: S.E. 
development. These results indicated that the wheat lines varied in their potential for $\alpha$-amylase induction in the soaked distal half-grains. Wheat lines such as RL4137 appeared to display this potential during grain development. The $\alpha$-amylase synthesis may take place in the aleurone tissue, since the pericarp, which has been reported to be responsible for $\alpha$-amylase synthesis during the early stages of grain development (Daussant and Renard 1987), is no longer active at later stages of grain development.

\section{Isozyme analysis}

The mature embryos of RL4137, incubated in water for $72 \mathrm{~h}$, showed 9 bands in the high $\mathrm{pI}$ region and 9 bands in the low pI region (Fig. 2). The same isozyme pattern with a much higher activity was observed in the half-grains incubated in $1 \mu \mathrm{M} \mathrm{GA}_{3}$ for $72 \mathrm{~h}$. The activity of these isozymes did not appear to be reduced by heat treatment at $70^{\circ} \mathrm{C}$ for 15 min. On the other hand, the half-grains soaked in water for $72 \mathrm{~h}$ showed 7 isozymes only in the low pI region; bands 12 and 15 were missing compared with the low pI isozyme pattern in the half-grains treated with $\mathrm{GA}_{3}$. These isozymes were not detected after the heat treatment (Fig. 2). They appeared to correspond to $\alpha$-amylase, since they were active on a $\beta$-limit dextrin substrate. These results suggest that the low $\mathrm{pI}$ isozymes induced in the aleurone tissue by soaking in water were different from the low pI $\alpha$-amylase induced in the aleurone tissue by $\mathrm{GA}_{3}$, even though the majority of the enzymes showed the same pI.

\section{Heat stability}

The heat stability of $\alpha$-amylase that was induced in half-grains incubated with either $\mathrm{GA}_{3}$ or water and in the embryos was compared by heating the crude extracts at temperatures of 50 to $70^{\circ} \mathrm{C}$ for $15 \mathrm{~min}$ (Fig. 3). Most of the activity of $\alpha$-amylase of the embryos and half-grains treated with $\mathrm{GA}_{3}$ persisted even after treatment at $70^{\circ} \mathrm{C}(67.5 \%$ activity in the embryos and $72.8 \%$ in the half-grains), while the activity of the enzyme induced in the half-grains by water alone decreased to $6.7 \%$ of the initial activity observed before soaking (Fig. 3C). The reduction of the $\alpha$-amylase activity was not due to the low activity in the half-grains, since the $\alpha$-amylase activity of the embryos and half-grains treated with $\mathrm{GA}_{3}$ was measured in an extract diluted to give similar absorbance at $620 \mathrm{~nm}$ to that of the extract from the water-soaked half-grains. These results are in agreement with previous findings revealing the heat-labile nature of the $\alpha$-amylases induced in the half-grains.

\section{Suppression by glucose and $A B A$}

The activity of $\alpha$-amylase synthesized in the embryos soaked for $72 \mathrm{~h}$ was $53.5 \pm 4.3 \mathrm{mU} / \mathrm{mg}$ (Fig. 4 ). When the embryos were incubated with glucose, the application of $20 \mathrm{mM}$ and $80 \mathrm{mM}$ glucose decreased the $\alpha$-amylase activity to 42.9 $\pm 8.4 \mathrm{mU} / \mathrm{mg}$ and $22.5 \pm 1.1 \mathrm{mU} / \mathrm{mg}$, respectively. The reduc-
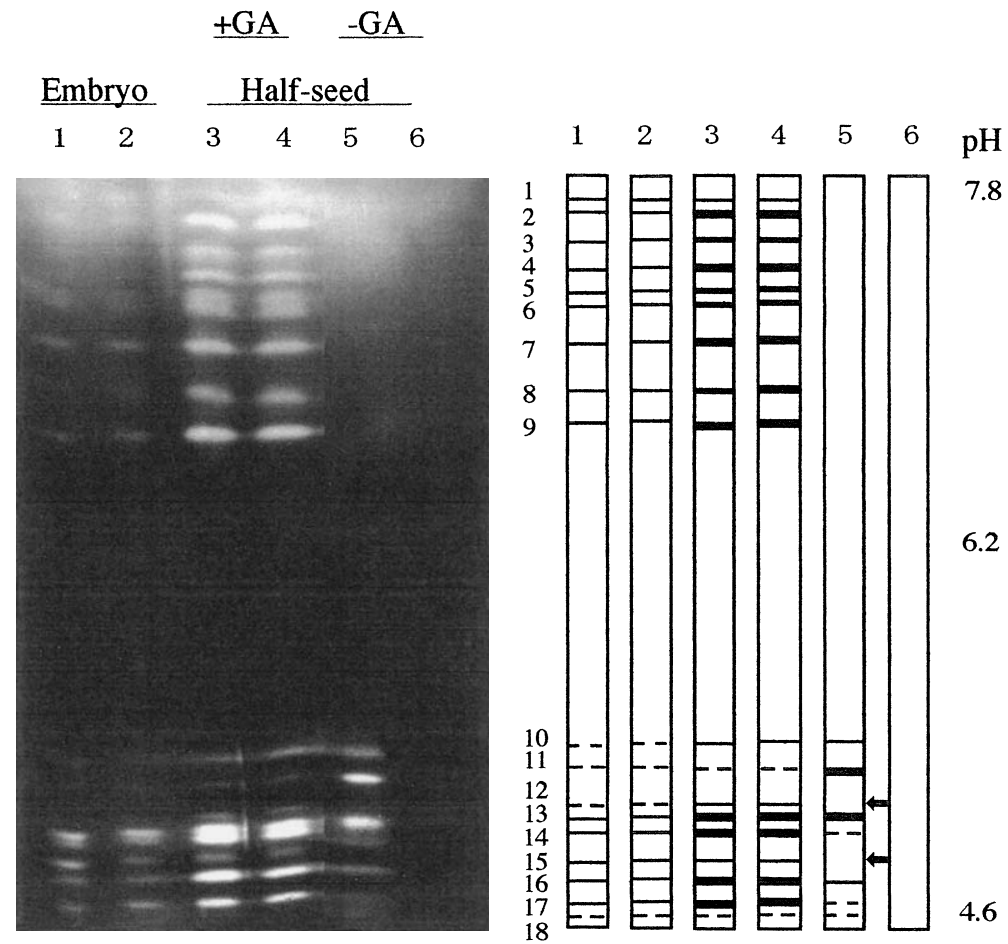

Fig. 2. Zymogram of $\alpha$-amylase induced in the embryos (Lanes 1,2) and distal half-grains of the wheat line RL4137 incubated in the presence (Lanes 3, 4) or absence (Lanes 5,6$)$ of $\mathrm{GA}_{3}(1 \mu \mathrm{M})$ for 72 hours at $20^{\circ} \mathrm{C}$ in darkness. Lanes 2, 4 and 6: heat treatment at $70^{\circ} \mathrm{C}$ for $15 \mathrm{~min}$. Bars: S.E. 


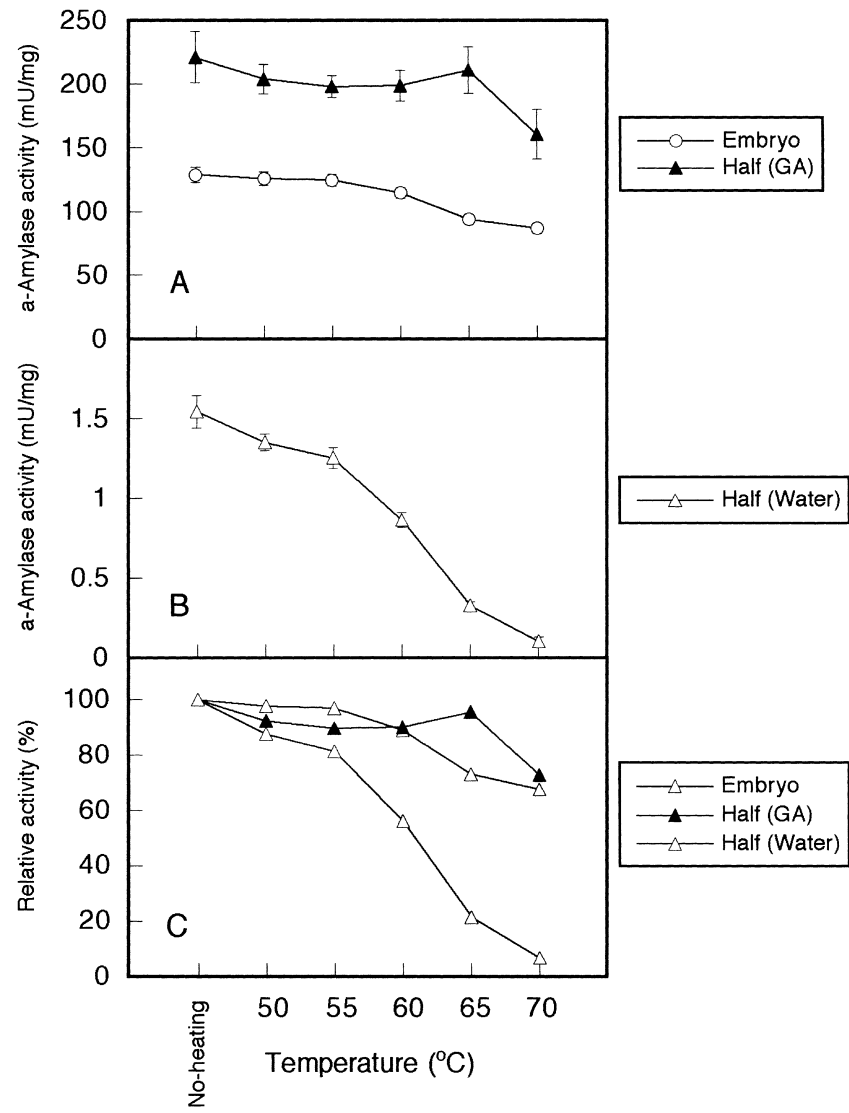

Fig. 3. $\alpha$-Amylase activity of the embryos incubated in water and of the distal half-grains of RL4137 in the presence or absence of $\mathrm{GA}_{3}(1 \mu \mathrm{M})$ for 72 hours. Crude extracts of $\alpha$-amylase were kept at room temperature or were subjected to heat treatment at $50,55,60,65$ and $70^{\circ} \mathrm{C}$ for $15 \mathrm{~min}$ before the assay.

(A) Embryos in water and distal half-grains incubated with $\mathrm{GA}_{3}$ at $20^{\circ} \mathrm{C}$.

(B) Distal half-grains incubated with distilled water at $20^{\circ} \mathrm{C}$ for 72 hours.

(C) Relative activity of $\alpha$-amylase in the embryos and distal half-grains incubated in the presence or absence of $\mathrm{GA}_{3}$.

Bars: S.E.

tion by the treatment with $80 \mathrm{mM}$ glucose was significant $(\mathrm{P}<0.05)$. A similar reduction was observed in $\alpha$-amylase synthesized in the half-grains incubated in the presence of glucose (Fig. 4B). The $\alpha$-amylase activities of the half-grains incubated in water, $20 \mathrm{mM}$ and $80 \mathrm{mM}$ glucose were $1.2 \pm 0.2$ $\mathrm{mU} / \mathrm{mg}, 0.7 \pm 0.03 \mathrm{mU} / \mathrm{mg}$ and $0.6 \pm 0.02 \mathrm{mU} / \mathrm{mg}$, respectively. The reduction by treatment with $20 \mathrm{mM}$ and $80 \mathrm{mM}$ glucose to $63.3 \%$ and $45.5 \%$ was significant $(\mathrm{P}<0.05)$, respectively (Fig. 4C). On the other hand, glucose did not exert any significant effect $(\mathrm{P}>0.05)$ in the distal half-grains treated with $1 \mu \mathrm{M} \mathrm{GA}_{3}: 94.8 \pm 1.8 \mathrm{mU} / \mathrm{mg}$ in $\mathrm{GA}_{3}, 92.6 \pm 5.4 \mathrm{mU} / \mathrm{mg}$ in $\mathrm{GA}_{3}$ plus $20 \mathrm{mM}$ glucose, $112.6 \pm 12.3 \mathrm{mU} / \mathrm{mg}$ in $\mathrm{GA}_{3}$ plus $80 \mathrm{mM}$ glucose (Fig. 4A).

In the embryos incubated with 10,20 and $40 \mu \mathrm{M} \mathrm{ABA}$, the $\alpha$-amylase activity was significantly lower $(\mathrm{P}<0.01)$, at $6.5 \pm 1.3 \mathrm{mU} / \mathrm{mg}, 6.6 \pm 1.6 \mathrm{mU} / \mathrm{mg}$ and $5.1 \pm 0.6 \mathrm{mU} / \mathrm{mg}$, respectively, compared to the value of $43.7 \pm 1.6 \mathrm{mU} / \mathrm{mg}$

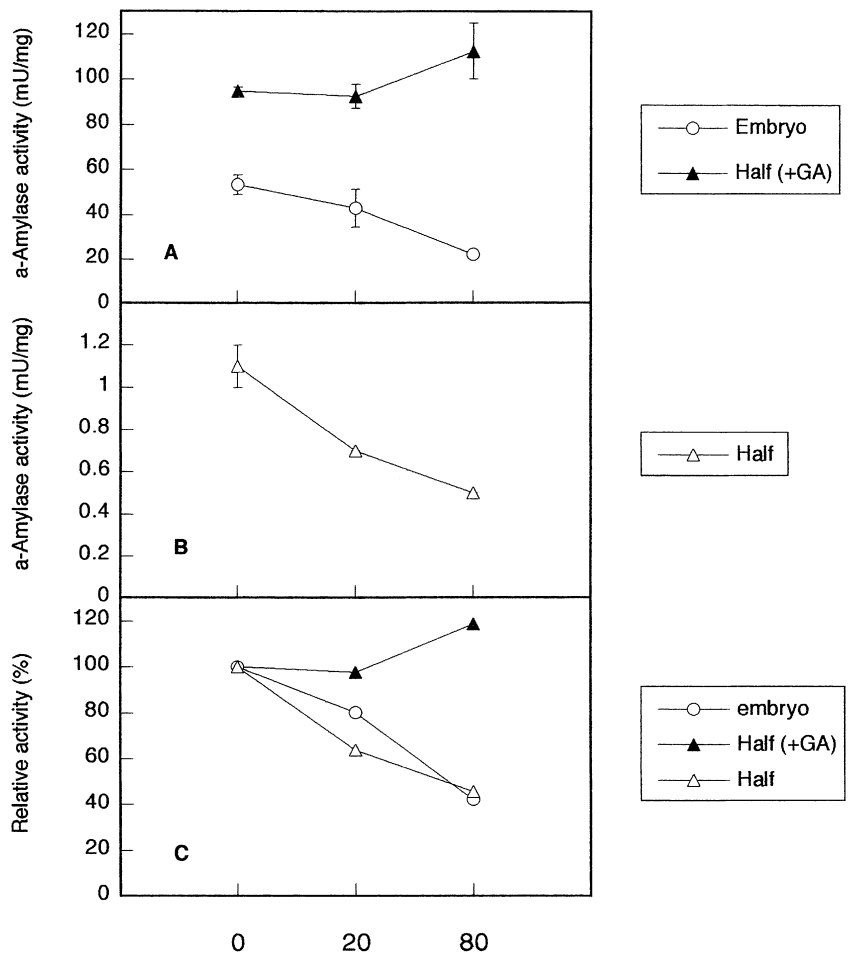

Glucose concentration (mM)

Fig. 4. $\alpha$-Amylase activity of the embryos incubated in water or glucose solution and of the distal half-grains of RL4137 in the presence or absence of $\mathrm{GA}_{3}$ with glucose solution for 72 hours. (A) Embryos in 0, 20 or $80 \mathrm{mM}$ glucose and distal half-grains in $\mathrm{GA}_{3}(1 \mu \mathrm{M})$ plus 0,20 or $80 \mathrm{mM}$ glucose.

(B) Distal half-grains in 0,20 or $80 \mathrm{mM}$ glucose.

(C) Relative activity of $\alpha$-amylase in the embryos and distal half-grains incubated in the presence or absence of $\mathrm{GA}_{3}(1 \mu \mathrm{M})$ with 0,20 and $80 \mathrm{mM}$ glucose.

Bars: S.E.

recorded in the embryos that had not been treated with $\mathrm{ABA}$ (Fig. 5A). ABA reduced the $\alpha$-amylase activity to a level of about $15 \%$ of that without $\mathrm{ABA}$ treatment on the average (Fig. 5C). A significant $(\mathrm{P}<0.01)$ reduction of the $\alpha$-amylase activity by $\mathrm{ABA}$ was also observed in the half-grains in the presence or absence of $\mathrm{GA}_{3}$ (Fig. 5A, B). The average reduction of the $\alpha$-amylase activity in the half-grains by ABA was about 50\% (Fig. 5C).

\section{Discussion}

The production of $\alpha$-amylase was induced in the halfgrains of RL4137 and Hokkai250, but not in those of OS215 and Shirogane. There was a variation in the potential of the aleurone tissue to synthesize $\alpha$-amylase among the wheat lines by soaking. This ability of the aleurone tissue to induce the production of $\alpha$-amylase did not appear to be related to the pre-harvest sprouting resistance or to the level of grain dormancy since RL4137 is known to be a line with preharvest sprouting resistance and a high level of dormancy. During grain development, RL4137 showed an $\alpha$-amylase 


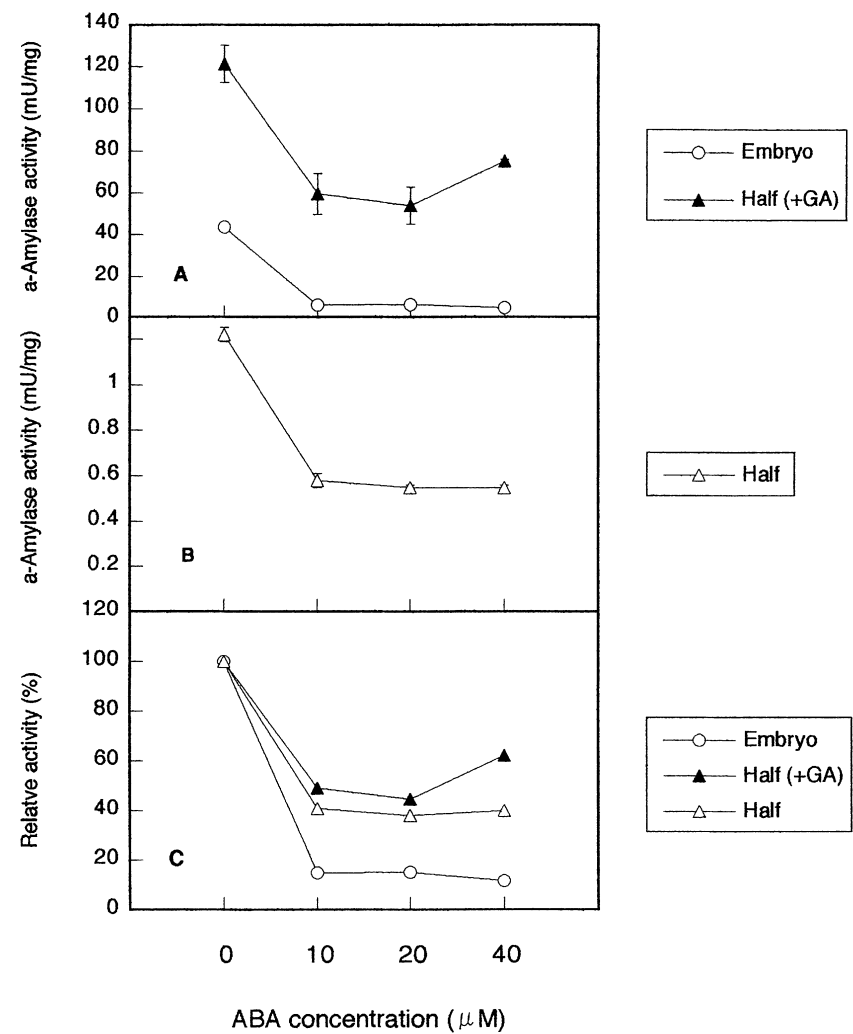

Fig. 5. $\alpha$-Amylase activity of the embryos of RL4137 incubated in water or $\mathrm{ABA}$ and of the distal half-grains in the presence or absence of $\mathrm{GA}_{3}$ plus $\mathrm{ABA}$.

(A) Embryos incubated in water and $\mathrm{ABA}(10,20$ or $40 \mu \mathrm{M})$ and distal half-grains in $1 \mu \mathrm{M} \mathrm{GA}_{3}$ plus $\mathrm{ABA}(10,20$ or 40 $\mu \mathrm{M})$.

(B) Distal half-grains incubated in ABA $(10,20$ or $40 \mu \mathrm{M})$.

(C) Relative activity of $\alpha$-amylase in the embryos and distal half-grains incubated in the presence or absence of $\mathrm{GA}_{3}$ with ABA $(10,20$ or $40 \mu \mathrm{M})$.

Bars: S.E.

activity of about $2 \mathrm{mU} / \mathrm{mg}$ ( $45 \mathrm{mU} /$ half-grain on the average) after soaking. It is possible that under wet conditions, the aleurone tissue of the developing grains of RL4137 might have contributed to the accumulation of $\alpha$-amylase in mature grains. Gale et al. (1983a) indicated that two wheat lines, MarisHuntsman and Bezostaya, showed a high $\alpha$ amylase activity (more than $10 \mathrm{mU} /$ grain) in field-grown mature grains, compared to two other wheat lines, KogaII and Bersee, which did not display any $\alpha$-amylase activity. RL4137 stood midway between these lines with high and low $\alpha$-amylase activity. They also suggested that $\alpha$-amylase produced during grain development in MarisHuntsman might represent the $\alpha$-AMY 1 family and contribute to an increase in the $\alpha$-amylase activity at the time of germination. Thus, although the level of the $\alpha$-amylase activity induced in soaked aleurone tissue was very low, the potential of the aleurone tissue to produce $\alpha$-amylase without GA signal from the embryo might also be one of the factors that reduce flour quality.
Wheat harbors 12-14 $\alpha$-Amyl genes for high pI isozymes $(\alpha$-AMY1) on the chromosomes of the homoeologous group 6 , while 10 or $11 \alpha$-Amy 2 genes for low $\mathrm{pI}$ isozymes $(\alpha$-AMY2) on the chromosomes of group 7 , and three $\alpha$-Amy3 genes for unusually high $\mathrm{pI}$ isozymes $(\mathrm{pI}>10$, $\alpha$-AMY3) on the chromosomes of group 5 (Baulcombe et al. 1987, Gale et al. 1983b, Huang et al. 1992). The $\alpha$-AMY2 isozymes were detected during early grain development and after five or six days throughout grain germination (Marchylo et al. 1979, 1980, Nishikawa and Watanabe 1988). Gale and Ainsworth (1984) and Baulcombe et al. (1986) suggested that the $\alpha$-Amy 2 expression was not controlled by GA in developing grains and that $\alpha$-AMY2 with the same pI might be encoded by a different $\alpha$-Amy 2 gene. Lunn et al. (1999) examined the heat-labile nature of $\alpha$-AMY 2 induced in the pericarp during grain development. Recent studies have showed that the expression of the $\alpha$-amylase genes decreased by treatment with sugars (Morita et al. 1998, Sheu et al. 1996, Loreti et al. 2000).

The present results indicated that the isozymes of $\alpha$ amylase induced in the aleurone tissue were heat-labile and lacked two low pI isozymes (bands 12 and 15), compared with the $\alpha$-amylase isozyme pattern in the aleurone tissue treated with $\mathrm{GA}_{3}$. Glucose also suppressed the expression of $\alpha$-amylase in the aleurone tissue soaked with water alone, but not in the aleurone tissue treated with $\mathrm{GA}_{3}$, although ABA suppressed both $\alpha$-amylases similarly. These results suggest that the induction of $\alpha$-amylase in the aleurone tissue may be similar to that of $\alpha$-AMY2 in the pericarp and might be encoded by $\alpha-A m y 2$ genes that are different from the $\alpha-A m y 2$ genes expressed in the aleurone tissue and embryos at the time of germination. Some wheat lines may maintain a potential to synthesize 'green' $\alpha$-AMY2 in the aleurone tissue during the middle to late stages of seed development.

\section{Acknowledgements}

The authors thank Dr. Yoichi Amano, Kitami Agricultural Experiment Station, for providing the seeds of the 68 wheat varieties/lines used in this study. We are also grateful to Mr. Takakazu Matsuura for his technical assistance. This work was supported by a grant from the Ohara Foundation for Agricultural Research.

\section{Literature Cited}

Barnes, W.C. and A.B.Blakeney (1974) Determination of cereal alphaamylase using a commercially available dye-labelled substrate. Stärke 26: 193-197.

Baulcombe, D.C., A.K.Huttly, R.A.Martienssen, R.F. Barker and M.G.Jarvis (1987) A novel wheat $\alpha$-amylase gene ( $\alpha$-Amy3). Mol. Gen. Genet. 209: 33-40.

Baulcombe, D.C., R.A. Martienssen, A.K.Huttly, R.F. Barker and C.M.Lazarus (1986) Hormonal and developmental control of gene expression in wheat. Philos. Trans. R. Soc. London, Ser. B 314: 441-451. 
Cornford,C.A., M.Black, J.M.Chapman and D.C.Baulcombe (1986) Expression of $\alpha$-amylase and other gibberellin-regulated genes in aleurone tissue of developing wheat grains. Planta 169: 420428.

Daussant, J. and H.A.Renard (1987) Development of different $\alpha$ amylase isozymes, having high and low isoelectric points, during early stages of kernel development in wheat. J. Cereal Sci. 5: 13-21.

Gale,M.D. and C.C.Ainsworth (1984) The relationship between $\alpha$ amylase species found in developing and germinating wheat grain. Biochem. Genet. 22: 1031-1036.

Gale,M.D., J. E.Flintham and E.D.Arthur (1983a) Alpha-amylase production in the late stages of grain development-an early sprouting damage risk period? In "Third International Symposium on Pre-Harvest Sprouting in Cereals" Kruger, J.E. and D.E. LaBerge (eds.), Westview Press, Boulder, Colorado, USA. p.29-35.

Gale,M.D., C.N.Law, A.J.Chojecki and R.A.Kempton (1983b) Genetic control of $\alpha$-amylase production in wheat. Theor. Appl. Genet. 64: 309-316.

Huang,N., G.L.Stebbins and R.L.Rodriguez (1992) Classification and evolution of alpha-amylase genes in plants. Proc. Natl. Acad. Sci. USA 89: 7526-7530.

Kettlewell,P.S., G.D.Lunn, B.J.Major, R.E.Scott, M.A.Froment and R.E.L.Naylor (1999) Development of a scheme for pre-harvest prediction of hagberg falling number in wheat. In "Eighth International Symposium on Pre-Harvest Sprouting in Cereals 1998" Weipert,D. (ed.), Federal Centre for Cereal, Potato and Lipid Research. Detmold, Germany, p. 9-14.

Loreti,E., C.Matsukura, F.Gubler, A.Alpi, J.Yamaguchi and P.Perata (2000) Glucose repression of alpha-amylase in barley embryos is independent of GAMYB transcription. Plant Mol. Biol. 44: $85-90$.

Lunn,G.D., P.S.Kettlewell, B.J.Major and R. K.Scott (1999) The contribution of pericarp activity and pre-mature sprouting to alpha- amylase activity in wheat grain. In "Eighth International Symposium on Pre-Harvest Sprouting in Cereals" Weipert,D. (ed.), Federal Centre for Cereal, Potato and Lipid Research. Detmold, Germany, p. 278-289.

MacGregor,A.W. (1976) A note on the formation of $\alpha$-amylase in deembryonated barley kernels. Cereal Chem. 53: 792-796.

Marchylo,B.A., L.J.LaCroix and J.E.Kruger (1979) The synthesis of $\alpha$-amylase in specific tissue of the immature wheat kernel. Cereal Res. Commun. 8: 61-68.

Marchylo,B.A., L.J.LaCroix and J.E.Kruger (1980) $\alpha$-Amylase isoenzymes in Canadian wheat cultivars during kernel growth and maturation. Can. J. Plant Sci. 60: 433-443.

Mares,D.J. and M.D.Gale (1990) Control of alpha-amylase synthesis in wheat grains. In "Proceedings of the Fifth International Symposium on Pre-Harvest Sprouting in Cereals" Ringlund, K., E.Mosleth and D.J.Mares (eds.), Westview Press, Boulder, Colorado. USA. p. 183-194.

Morita,A., T.Umemura, M.Koruyanagi, Y.Futsuhara, P.Perata and J.Yamaguchi (1998) Functional dissection of a sugar-repressed $\alpha$-amylase gene (RAmylA) promoter in rice embryos. FEBS letters 23: 81-85.

Nishikawa, K. and Y.Watanabe (1988) Change in activity of alphaamylase in developing and germinating wheat seed. In "7th Int. Wheat Genetics Symposium" Miller,T.E. and M.D.Koebner (eds.), Bath Press, Bath, UK. p. 597-602.

Sargeant, J.G. and T.S. Walker (1978) Adsorption of wheat alphaamylase isozymes to wheat starch. Starch 30: 160-163.

Sargeant,J.G. (1980) $\alpha$-amylase isoenzymes and starch degradation. Cereal Res. Commun. 8: 77-85.

Sheu,J.J., T.S.Yu, W.F.Tong and S.M.Yu (1996) Carbohydrate starvation stimulates differential expression of rice alpha-amylase genes that is modulated through complicated transcriptional and posttranscriptional processes. J. Biol. Chem. 271: 2699827004. 